\title{
Teachers' attitudes, perceptions and experiences in CLIL: A look at content and language
}

\section{Actitudes, percepciones y experiencias de los profesores en AICLE: una mirada al contenido y al lenguaje}

Jermaine McDougald ${ }^{1}$

Citation / Para citar este artículo: McDougald, J. (2015). Teachers' attitudes, perceptions and experiences in CLIL: A look at content and language. Colomb. Appl. Linguist. J., 17(1), pp. 25-41.

Received: 14-Oct-2014 / Accepted: 25-Mar-2015

DOI: http://dx.doi.org/10.14483/udistrital.jour.calj.2015.1.a02

\begin{abstract}
This paper is a preliminary report on the "CLIL State of the Art" project in Colombia, drawing on data collected from 140 teachers' regarding their attitudes toward, perceptions of, and experiences with CLIL (content and language integrated learning). The term CLIL is used here to refer to teaching contexts in which a foreign language (in these cases, English) is the medium for the teaching and learning of non-language subjects. The data that has been gathered thus far reveal that while teachers presently know very little about CLIL, they are nevertheless actively seeking informal and formal instruction in CLIL. Many of the surveyed teachers are currently teaching content areas through English; approximately half of them reported having had positive experiences teaching content and language together, though the remainder claimed to lack sufficient knowledge in content areas. Almost all of the participants agreed that the CLIL approach can benefit students, helping them develop both language skills and subject knowledge (meaningful communication). Nevertheless, there is still considerable uncertainty as to the actual state of the art of CLIL in Colombia; greater clarity here will enable educators and decision-makers to make sound decisions for the future of general and language education.
\end{abstract}

Keywords: bilingual education, CLIL, content and language, teacher beliefs

\section{Resumen}

El artículo es un informe preliminar sobre el proyecto "CLIL State-of-the-Art" en Colombia, a partir de los datos recolectados de 140 docentes con respecto a sus actitudes ante las percepciones y experiencias con AICLE (Aprendizaje Integrado de Contenidos y Lengua). El término CLIL (AICLE) se utiliza aquí para referirse al contexto educativo en el que una lengua extranjera (en estos casos, inglés) es el medio para la enseñanza y el aprendizaje de asignaturas que no son de lengua. Los datos que se han recopilado hasta la fecha revelan que aunque los docentes actualmente saben muy poco sobre CLIL, buscan activamente la formación formal e informal en CLIL. Muchos de los docentes encuestados actualmente están enseñando materias de contenido a través del inglés; aproximadamente la mitad de ellos informó haber tenido experiencias positivas de enseñanza de contenidos y lenguaje juntos, aunque el resto manifestó falta de conocimiento suficiente en las áreas de contenido. Casi todos los participantes coincidieron en que el enfoque AICLE puede beneficiar a los estudiantes, ayudándoles a desarrollar tanto las habilidades de lenguaje como conocimiento de la materia (comunicación significativa). Sin embargo, todavía hay una considerable

1 Universidad de La Sabana, Chía, Colombia. jermaine.mcdougald@unisabana.edu.co 
incertidumbre sobre el estado real del enfoque de CLIL en Colombia; mayor claridad aquí permitirá a los educadores y directivos tomar decisiones acertadas para el futuro de la educación general y la educación en lengua.

Palabras clave: AICLE, CLIL, contenido y lenguaje, creencias de docentes, educación bilingüe

\section{Introduction}

There has been a great deal of discussion regarding the topic of content and language integrated learning (CLIL) and its role in bilingual education in Colombia. There are still many researchers and practitioners who are not sure what CLIL is or how it could be included in their curricula. In recent years, surveys have been employed successfully by both government- and university-level research projects around the world to gather information about the implementation of CLIL (Nikula \& Marsh, 1996; Yassin, Marsh, Tek, E Ying, 2009), thereby providing valuable information for educators, administrators, and policy-makers. Not only do such surveys provide a snapshot of the current state of affairs regarding CLIL, but the evergrowing data set from cumulative surveys conducted over time facilitates a comparative analysis of developing trends at both the local and international levels. Even so, such surveys thus far have not been conducted regarding attitudes, perceptions, or even experiences in the Colombian context; by doing so, decision makers would gain access to valuable information that would help them make betterinformed decisions regarding the implementation of CLIL in Colombia.

The CLIL surveys that were conducted in Europe and Asia offer promising models for similar research in Colombia and elsewhere in Latin America. Furthermore, they also make it clear that the specific contexts of different countries and regions need to be taken into account in developing new CLIL surveys (Eurydice, 2006; Yassin et al., 2009). Accordingly, the present study specifically considered the particular nature and context of language education in Colombia and Latin America while nevertheless simultaneously maintaining a broad similarity with CLIL surveys conducted in Europe, Southeast Asia, and elsewhere, so as to provide comparative data for researchers and educators worldwide.
This paper reports on a preliminary study that forms part of a larger study with the objective of collecting data regarding the current state of the art of CLIL implementation (including educator/ learner attitudes towards CLIL) in Latin American educational institutions. The present paper only reports on a relatively small number of participants in Colombia, and focuses on teachers' perceptions and experiences with CLIL. Furthermore, this study will also form a basis for the further development of a wider study in Colombia (and Latin America) that would be of immediate value and its applicability for educators, researchers, and policy-makers and that would simultaneously place Latin American research on CLIL within a broader global context.

\section{Background of the study}

To date, there is no concrete data on the current state of the art of CLIL in Colombia. There have been different initiatives to implement CLIL programs and provide CLIL training, though many of these initiatives have been isolated, with no clear connection with other institutions and/ or initiatives. Still, despite such initiatives and programs, "many Colombian teachers are still unaware of the CLIL work being carried out in their own context" (Curtis, 2012, p. 9). Mehisto and Asser (2007), and Mehisto (2008) both note that the lack of knowledge stakeholders have with regard to aims is one of the chief issues that must be addressed in CLIL implementations. In order for administrators to implement CLIL programs responsibly, serious needs analysis must be carried out before any actions actually begin (Butler, 2005; Ruiz-Garrido E Fortanet-Gómez, 2009). A lack of awareness or knowledge among administrators is closely linked to those who are in charge of implementing CLIL: teachers. As Butler (2005) points out, implementing CLIL "requires careful consideration and tremendous commitment by teachers, administrative staff, and others" (p. 233). 
Therefore, to know where to start in terms of CLIL implementation, it is vital to conduct a survey gathering information on teachers' perceptions of CLIL. This information could be used to support CLIL implementations in the approximately 175 bilingual schools officially registered in Colombia (Colombia MEN, 2009) in which more than $50 \%$ of the subjects at the primary or secondary level are taught through English, or through Spanish, French, Italian or German (Rodriguez, 2011). Moreover, there are 72 schools $^{2}$ with internationalized curricula in Colombia, including those implementing the International Baccalaureate (IB) program, Cambridge International Examinations (CIE), the International Curriculum and Southern Association of Colleges and Schools (SACS) (see Table 1).

Table 1. No. of Schools with International Curriculum in Colombia

\begin{tabular}{cccc}
\hline Cities in Colombia & CIE & IBO & SACS \\
\hline Armenia & 0 & 0 & 1 \\
Bogota & 7 & 17 & 2 \\
Barranquilla & 1 & 3 & 3 \\
Bucaramanga & 3 & 0 & 1 \\
Chia & 0 & 2 & 0 \\
Cajica & 0 & 2 & 0 \\
Cali & 3 & 4 & 1 \\
Cartagena & 3 & 0 & 1 \\
Manizales & 2 & 0 & 1 \\
Medellin & 5 & 2 & 1 \\
Neiva & 2 & 0 & 0 \\
La Guajira & 0 & 1 & 0 \\
Pereira & 0 & 1 & 2 \\
Santa Marta & 0 & 0 & 1 \\
NOTAL NO. OF SCHOOLS & 26 & 32 & 14 \\
WITH INTERNATIONAL & 72 & & \\
PROGRAMS & & & \\
\hline
\end{tabular}

According to Secretaria de Educación (SED) of Bogota (2012) the following characteristics define the different types of bilingual schools (International Bilingual School, National Bilingual School and

2 Information was taken from the following sites:

(IB) http://ibo.org/school/search/index.cfm?nextStart=2

(CIE) http://www.britishcouncil.co/examen/escuelas-cie

(SACS) http://www.advanc-ed.org/oasis2/u/par/

search;jsessionid=3EF3E6E4D0AC24876D8DEA5DD983B89D
Intensification in a Foreign Language [Programas intensivos de inglés]) that manage programs in a second and/or foreign language in Colombia:

- International Bilingual Schools: These have close links with official organizations from a foreign country. This type of school receives direct financial support from their governments or imports foreign teachers to work in the school. There is a high amount of contact with the foreign language in the curriculum (over $50 \%$ ). Two or more languages are used as a means of learning in different curricular areas. These schools use materials and texts imported from abroad, promote direct contact between their students and the foreign country through exchanges or internships, require their graduates to pass an examination for the foreign language in addition to passing the Colombian curriculum requirements, and promote bicultural or intercultural orientation (SED, 2012).

- National Bilingual Schools: There is a high amount of contact with the foreign language in the curriculum (over 50\%), and two or more languages are used in the teaching and learning for different curricular areas. School administrators are Colombian nationals. The majority of the teachers are Colombian bilinguals. They also require their graduates to pass an examination for the foreign language in addition to passing the Colombian curriculum requirements. They promote intercultural orientation (SED, 2012).

- Schools with Intensified Foreign Language: These establishments dedicate at least an average of 10-15 hours per week to learning a foreign language as a subject, but this is not used as a medium for learning in any curricular area. They also require their students to pass a foreign language exam before completing their studies (SED, 2012).

The current study included 140 in-service teachers teaching content area subjects in English. There were a range of teachers from various areas, grades, and sections, including preschool, primary, secondary, and higher-education institutions. This particular population was chosen because the 
different educational institutions from which they came were interested in CLIL and/or instructing courses containing content and language. The questionnaire, "Teacher's Attitudes, Perceptions $\mathcal{E}$ Experiences in CLIL" (Appendix A) which was used for this study, was organized into 10 subject areas so that participants were free to respond to questions relevant to the subject areas they taught. Ranked according to the number of respondents in each of the main subject areas in which participants taught were (1) English literature, (2) science/biology (3) technology and information technology (4) mathematics/physics, and (5) geography-social studies.

\section{Literature review / Theoretical considerations}

\section{Language and content instruction in Colombia}

Content and Language Integrated Learning (CLIL) is becoming a familiar word in many bilingual schools in Colombia, where "bilingualism is starting to take on a new role where schools and universities are not concerned with just learning English anymore, but are more concerned as to what students can do with the new language" (McDougald, 2009, p. 44). Habte-Gaber (2009) argues that CLIL tends to generate a sense of order in that it formalizes diverse professional and personal life experiences under a pedagogical approach. Nonetheless, the true meaning of CLIL still seems to be a gray area for many. Content and language instruction is not new to Colombian teachers, as many have been immersed in an environment where English has been used to teach content area subjects such as science, mathematics, arts, social studies, or even language arts in primary and secondary education programs. Rodriguez (2011) highlights the different types of bilingual institutions in Colombia from International Baccalaureate (IB) schools, Americanstyle schools, and British-style schools where 50\% of the curriculum is taught in English. Many of these types of schools have existed for more than 40 years, reaffirming that language and content instruction in Colombia is not a wholly new concept. There have also been related initiatives from higher educational institutions, in which there has been a strong emphasis on learning content through English, as well as enforcing International English exam requirements for graduates with the intention of making them more competitive with their international peers. Graddol (2005) discusses the issue of globalization in higher education arguing that "students should not just become conversant in 'general English,' but should study their subjects in English" (p.2). Examining the curricula and study plans of top-ranked universities in Colombia shows that they all seem to include a strong emphasis on teaching and learning in English across the curriculum, theoretically providing their graduates with a competitive edge through the use of English in an academic environment. This moreover enhances students' opportunities to win internships aboard, or positions in multinational companies where bilingualism is a must. Knowledge of English provides many universities with access to the latest academic materials, as well as permitting university staff to publish in English (Graddol, 2005).

Colombia has seen some context-specific CLIL initiatives, such as the Latin American Journal of Content $\mathcal{E}$ Language Integrated Learning, a peerreviewed academic publication aimed at teachers, researchers, and educational administrators throughout Latin America and around the world who are interested in researching, implementing, or improving language-learning approaches, techniques, materials, and policies that has been published twice a year since 2008. Its main focus (according to the journal's Web site) is CLIL, as well as multilingualism, interculturalism, and CALL (computer-assisted language learning) (LACLIL, 2013). There have also been some formal teacher training programs geared towards in-service teachers for CLIL provided by universities, publishing houses, and private institutions.

\section{Content instruction}

Cross and Gearson's (2012) recent study discusses the results from six different case studies of CLIL implementation. Their report highlights a large number of strategies and techniques that have been implemented in CLIL approaches. Furthermore, they identify key areas that should be considered when implementing CLIL, and strategies that have 
been successful as well as points of caution and challenges. Marsh (2006) reminds us that "CLIL offers opportunities for learners to use another language different than their mother tongue in a more natural way, so that they soon forget about the language and focus only on learning the topic" (p. 6). Darn (2012) defines CLIL as the meeting point of content and language in space (the classroom) and time (the lesson). Coyle, Hood, and Marsh (2010) describe CLIL as a developing, flexible concept in which content (i.e. non-language subject/s, crosscurricular themes, and holistic issues) and foreign languages are integrated in some kind of mutually beneficial way so as to provide motivating, valueadded experiences to educational outcomes for a wide range of students. Marsh, Mehisto, Wolff, and Frigols Martín (2011, p.18) define successful content learning as being dependent on language; however, enhanced language learning is dependent on content learning. Research-based knowledge of the interdependence of language (L1, L2, L3) and cognitive development facilitates both content and language learning.

There is also an array of similarities and shared characteristics between CLIL and more traditional forms of bilingual educational programs. Contentbased instruction (CBI), well known and used in both North and South America, dates back to the 1960s, while interest in teaching language for specific professional and educational purposes has long led educators to explore the inclusion of meaningful content in language classrooms (Brinton, Snow, E Wesche, 2006; Grabe $\&$ Stoller, 1997). It also seems safe to say that much of CBI has been focused upon language for specific purposes (LSP), an approach that has likewise seen an increased focus over the past twenty years on primary, secondary, and university language instruction (Snow $\mathcal{E}$ Brinton, 1997).

\section{CLIL implementation}

Studies have been carried out on the implementation of CLIL in different educational contexts. Unfortunately, there have not been many studies on CLIL implementation in Colombia. In a longitudinal study carried out in Germany, Massler (2012) focused on Pro CLIL stakeholder groups with the overall objective of finding out how teachers, parents, and children experience the implementation of CLIL modules at the primary level. Massler concluded that in general all of the teachers who participated in the study considered CLIL a positive teaching approach and that CLIL students experienced CLIL language learning differently from regular foreign-language teaching. Stakeholders in this study also found the CLIL modules were "enriching and also increased their understanding of CLIL" (p. 44) while acquainting teachers and students with the CLIL concept, offering them an opportunity to experiment using the CLIL approach, methods, and learning materials. The author does not specify as to what components are better or different (CLIL approach vs. traditional foreign-language class), yet he suggests that further research would be needed to help explain whether language proficiency will improve after long-term exposure to CLIL for both high and low achievers in reaching the learning outcomes.

A small scale study by Savic (2010) sought to discover whether Serbian EFL teachers were ready to implement CLIL in their classrooms and explored teachers' attitudes and experiences as well as the potential benefits of using a CLIL approach. The results suggested that many of the teachers were not familiar with CLIL and had a "very vague idea of what CLIL refers to" (p. 3). The author also discussed the drawbacks related to CLIL and the teacher competences required to teach English and content, e.g. "applying appropriate pedagogical practices involving problem-solving, negotiations, discussions and classroom management" (p.4). The study concludes with specific recommendations for more teacher training on CLIL, lesson planning, and relevant content knowledge.

A study carried out by Pena Diaz and Porto Requejo (2008) on teachers' beliefs on CLIL among 150 primary-level schools in Spain similarly revealed that specially designed teacher training courses were needed. Teachers who participated in the study complained about the lack of time available to complete activities inside and outside of the classroom, in response to which the authors suggested creating online training courses. This particular teacher population also reported having 
low self-esteem due to their low levels of proficiency in the additional language. Even so, the participants claimed that they did not need additional training concerning bilingual methodology, yet they showed interest in practical knowledge on their specific subjects.

A study on integrating CLIL at the tertiary level by Dafouz, Núñez, Sancho, and Foran (2007) in Madrid, Spain looked at 85 undergraduate students in chemistry, health sciences and aeronautical engineering who were enrolled in core elective ESP courses that were delivered entirely in English and 70 teachers who gave their views about implementing a CLIL approach. Their results revealed a positive attitude towards CLIL implementation amongst teachers and students, as well as a need for interactive classes. They found that the majority of the polled teachers were willing to get involved in CLIL projects and develop additional materials, providing that financial and methodological support from local government authorities was given. Students were somewhat reluctant to engage with the CLIL approach, expressing that the same courses were already challenging in Spanish (L1) let alone in English. In conclusion, the authors recommend that more training be conducted in both methodology and evaluation.

Johnson (2012) also carried out a small scale case study amongst five lecturers, all holding doctoral degrees, at a teacher training college in Alcalá de Henares, Spain, focusing on how the participants' beliefs developed and/or changed over the course of a two-and-a-half year teacher development program focused on CLIL. The findings suggest that the additional CLIL training course was successful. The course allowed the participants' knowledge of CLIL to increase, thereby providing them with enhanced tools to teach through English. Furthermore, their beliefs about how knowledge is acquired changed, thereby generating a new attitude using a CLIL approach in their classes.

All of the studies mentioned above reinforce the need for a study of this nature to determine the current state of the art regarding CLIL implementation in both Colombia as well as Latin America. The aforementioned literature highlights gaps that can be seen as opportunities (in areas such as implementation, training at both at the pre-service and in-service level, and management of stakeholders) for CLIL practitioners. Critically, it remains unclear how CLIL/content and language are being managed or taught in classrooms throughout Colombia. The uncertainties surrounding implementation, participation from administrators, and overall perceptions need to be explored so that decision makers can make well-informed choices on current and/or future CLIL initiatives within the Colombian context, which in turn can serve as useful starting points for evaluating other initiatives throughout the developing world.

\section{Methodology}

The present study utilized a survey-based research methodology modeled on that used to prepare the 2006 CLIL report by the European Union's research bureau (Eurydice, 2006). Webbased surveys were chosen due to the fact that the target population was dispersed throughout Colombia in more than 15 major cities. According to Fricker and Schonlau (2002), "web surveys are faster; and, combined with other survey modes, web surveys yield a higher response rate than the other survey modes by themselves" (p. 16). Moreover, when the population to be surveyed already uses the Internet frequently, the web makes fast and effective surveys practical (Check $E$ Schutt, 2012) making them ideal data collection tools for this study.

The questionnaire used in this study (Appendix A) was adapted from Savic's (2010) questionnaire that was used to survey English teachers working in Serbian schools. The questionnaire consisted of two parts. There were eight items in the first part related to personal information, demographics, subjects taught, and the students' age range. The second part consisted of twenty items concerned with attitudes and experiences in CLIL. A Likert scale was used, ranging from "strongly agree" to "strongly disagree," or simply "yes" or "no." The questions were generally completed online, although there were some instances in which the respondents completed the questionnaire by hand. 


\section{Survey designs}

The surveys were designed as seen in Table 2 which outlines the type of design, the anticipated setting, and the structure of the questions. Although the majority of the questionnaires were completed online using Google Forms, the other designs were necessary to follow up on participants' responses, to verify certain elements of the responses as well as to validate the information received. After administering the questionnaire, data were entered into IBM's statistical analysis software program SPSS version 21 , which was used to calculate percentages, mean scores, standard deviations, and correlations.

Table 2. Survey Designs

\begin{tabular}{ccc}
\hline Design & Setting & Questionnaire Structure \\
\hline Web Survey & Individual & Mostly Structured \\
Group Survey & Group & Mostly Structured \\
In-person Interviews & Individual & Structures or Unstructured \\
\hline
\end{tabular}

In accordance with Adams and Cox (2008), different types of questions were included in the questionnaire given the fact that these questions "require different levels of interpretation by the readers" (p. 20). The questionnaire used in the current study included simple factual information requiring yes or no responses (5), complex factual questions (4) which required some interpretation or analysis by the reader, and opinion or attitudinal questions (14) which required more alternatives and deeper concentration.

\section{Data collection and analysis}

The first instrument used was a survey based on a Likert Scale in which the perceptions and experiences of the teachers regarding CLIL were collected. The surveys were done in person as well as online. The first part of the survey was intended to collect personal and background data on subjects taught in a foreign language. The remaining parts of the survey focused on attitudes and perceptions in CLIL.

\section{Participants}

The teachers that participated ranged from teachers of English at the primary and secondary levels as well as university teachers who teach English as a foreign language, economy, business administration, accounting, psychology, engineering, etc. Of the 200 teachers invited to participate, only 140 accepted to participate and the remaining declined due to time constraints and availability. The teachers that participated in the initial phase of the project worked in both public and private educational institutions. The questionnaire was given to teachers from 10 educational institutions and 12 regional areas throughout Colombia whose ages ranged from 21-30 with an average of 8.3 years of teaching experience.

\section{Findings and Discussion}

After consolidating and analyzing the preliminary data among the 140 respondents from the questionnaire, Table 3 clearly highlights that there are still many teachers who are not aware of the CLIL approach even though many of them are currently teaching content in English and or some form of English as a foreign or second language.

Table 3. Correlation between CLIL Knowledge and Subject(s) Taught through English

\begin{tabular}{lcc}
\hline \multicolumn{1}{c}{ Item (item number) } & Mean & SD* $^{*}$ \\
\hline 1. How much do you know about CLIL? & 1.979 & 0.6053 \\
2. Subject(s) taught in a foreign language & & \\
3. I have already taught content through & 1.561 & 0.5532 \\
English. & & \\
\hline
\end{tabular}

*This standard deviation is understood to be merely indicative of the trends found in this study due to the low number of teachers involved in the preliminary phase of the study. 
Table 4. Knowledge about CLIL

\begin{tabular}{ccccc}
\hline \multicolumn{5}{c}{ 1. How much do you know about CLIL? } \\
\hline & Frequency & Percentage & Valid Percentage & Accumulated Percentage \\
A little & 85 & 60,7 & 60,7 & 60,7 \\
A lot & 27 & 19,3 & 19,3 & 80,0 \\
Ageee & 4 & 2,9 & 2,9 & 82,9 \\
Not much & 24 & 17,1 & 17,1 & 100,0 \\
TOTAL & 140 & 100,0 & 100,0 & \\
\hline
\end{tabular}

The results were surprising since a large percentage $(61 \%)$ of the participants knew a little about CLIL, taking into consideration that CLIL initiatives have been in Colombia for more than a decade even though they have been quite isolated. The majority of the teachers that participated in this preliminary stage of the study worked in public institutions (63.6). There were 89 teachers who reported having worked in public institutions and 51 in private institutions. The findings thus far suggest that the teachers who are not knowledgeable on CLIL are those who work in higher educational institutions. This could be related to the fact that a CLIL approach in Colombia has mainly taken place at the primary and secondary level.

Fifty percent of the respondents are teaching content through English as seen in Table 5. These preliminary results show that teachers are familiar with teaching subjects other than English in English; nonetheless, when asked if more knowledge on methodology was needed, $45 \%$ of the respondents agreed and $36 \%$ disagreed. When asked whether or not more subject knowledge was needed $41 \%$ agreed that subject knowledge was needed and $41 \%$ disagreed. This is an indicator that many of the teachers are not ready to teach subjects in English and many of them have been forced to teach subjects of which they have no real knowledge. Furthermore, they were selected to teach content subjects in English because of their excellent command of the language without any thought as to whether or not the teachers were properly trained in that area (methodology on how to teach content and language) or even well versed in the subject area.

However, despite the fact that many teachers lack skills on combing content and language, 52\% reported having had a positive experience teaching content through English and $96 \%$ feel as if CLIL benefits students as seen in Table 6.

When asked whether CLIL did or did not only develop students' subject knowledge, the majority of the participants (89\%) disagreed, and when asked if a CLIL approach developed language skills and subject knowledge, $100 \%$ of the respondents strongly agreed as shown in Table 7.

Table 5. Content Subjects Being Taught in English

\begin{tabular}{ccc}
\hline Item (item number) & Mean & SD* $^{\star}$ \\
\hline 4. I have already taught content area(s) through English. & 1.561 & 0.5532 \\
\hline
\end{tabular}

Table 6. Positive Experience Teaching Subject Content though English

\begin{tabular}{llc}
\hline \multicolumn{1}{c}{ Item (item number) } & Mean & SD* $^{\star}$ \\
\hline $\begin{array}{l}\text { 5. My experience in teaching subject content through English has been } \\
\text { positive }\end{array}$ & 2.986 & 1.596 \\
6. CLIL benefits students & 1.907 & 0.988 \\
\hline
\end{tabular}


The preliminary results regarding questions on lesson planning, methodology, and subject knowledge concluded that among these participants, only $40 \%$ expressed that subject knowledge was needed in order to teach content subjects in English. This indicates that many of the teachers feel confident in the content subjects that are being currently taught. Appendix B provides a list of subject(s) taught in a foreign language in accordance with the responses received.

Nevertheless, it was noted that "time was needed for lesson planning and teaching" (92\%), which was also a topic that came up in phone interviews, informal discussions, and formal training sessions (workshops delivered as part of the short CLIL training courses that I delivered) on CLIL with teachers when introducing a module on unit planning and lesson planning. Teachers expressed their concerns about the time needed to include additional components corresponding to Coyle's (1999) 4Cs (communication, content, cognition, and culture). This is comparable with Savic's (2010) findings in which three-quarters of the teachers were aware that CLIL lessons require a considerable amount of time for lesson planning and teaching.
When using a CLIL approach, time is a factor that concerns many teachers. Moreover, in both training sessions and informal meetings, many teachers expressed the concern that administrators and coordinators did not take "time" into consideration when deciding to implement a CLIL approach. Teachers also mentioned that they dedicate large quantities of time to class preparation-even without including a CLIL approach-which is something that influences less proactive attitudes towards adopting CLIL in their classrooms even when there has been an institutional decision to implement CLIL.

However, only $50 \%$ of the teachers agree that "CLIL requires a lot of administrative support" in order to make the implementation process a success followed closely by $27 \%$ who strongly agree. On the other hand, most of the teachers strongly agree (44\%) and agree $(42 \%)$ that CLIL requires cooperation with subject teachers, even though $48 \%$ of respondents claim to "have helped subject teachers teach content through English." Thus, regarding teamwork and administrative support, it is safe to say that the majority of the teachers see this as an important aspect in making the implementation a success. See Table 8 on cooperation and administrative support.

Table 7. Questions Referring to CLIL Development of Language Skills and Subject Knowledge

\begin{tabular}{lll}
\hline \multicolumn{1}{c}{ Item (item number) } & Mean & SD* $^{\star}$ \\
\hline 7. Does CLIL help students develop only their language skills? & 3.000 & 0.914 \\
8. Does CLIL help students develop only their subject knowledge? & 3.057 & 0.888 \\
9. Does CLIL help students develop both their language skills and subject & 1.900 & 0.991 \\
knowledge? & 2.579 & 1.188 \\
10. CLIL requires more methodology knowledge than ELT teachers possess. & \\
\hline
\end{tabular}

Likert scale with 1 indicating "Strongly Agree", 2 "agree", 3 "Disagree", "Strongly Disagree, and 5 "N/A" (SD = standard deviation).

Table 8. Questions Referring to Cooperation and Administrative Support

\begin{tabular}{lll}
\hline \multicolumn{1}{c}{ Item (item number) } & Mean & SD* $^{\star}$ \\
\hline 5. I have helped subject teachers teach subject content through English. & 1.607 & 0.596 \\
13. Does CLIL require a lot of time (both lesson planning \& teaching ) & 2.229 & 0.932 \\
14. Does CLIL require new teaching materials? & 2.221 & 1.080 \\
15. Does CLIL require a lot of administrative support? & 2.286 & 1.020 \\
16. Does CLIL require cooperation with subject teachers? & 1.864 & 0.770
\end{tabular}

Likert scale with 1 indicating "Strongly Agree", 2 "agree", 3 "Disagree", "Strongly Disagree, and 5 "N/A" (SD = standard deviation). 
Table 9. Questions Referring to the Age Level of CLIL Students

\begin{tabular}{lcc}
\hline \multicolumn{1}{c}{ Item (item number) } & Mean & SD* $^{\star}$ \\
\hline 17. Is CLIL only possible for young learners (YL)? & 3.200 & 0.788 \\
18. Is CLIL only possible for intermediate students of English? & 3.114 & 0.636 \\
19. Is CLIL only possible for older students? & 3.043 & 0.656 \\
\hline
\end{tabular}

When asked whether or not a CLIL approach was for only young, intermediate, or older learners, the results revealed that it is believed that CLIL could be used for any age level and is not restricted to a certain educational level (i.e. primary, secondary, among others).

\section{Conclusions}

The preliminary findings revealed that CLIL is not well known among Colombian English-teachers, though it is they who are often the teachers of content-area subjects in English, confirming the hypotheses that led to the initial implementation of the survey. Nonetheless, only half of the respondents claimed that they are currently teaching content through English, which may be due to the fact that since teachers lack knowledge regarding CLIL, this may likely reduce the effectiveness of language teachers (or anyone) who is teaching content through a second or foreign language.

All polled teachers reported that CLIL is beneficial for their learners and that a CLIL approach develops both subject knowledge skills and language skills. The findings are very similar to the study conducted by Savic (2010) who determined that $92 \%$ of the participants from primary agreed that CLIL developed both language skills and content knowledge. This is a clear indicator that teachers are interested in utilizing CLIL in their teaching contexts even though they have expressed concerns related to their workload in the event that a CLIL approach is adapted in their institutions.

Additionally, the majority of the teachers reported that they needed more knowledge on methodology and/or the subject at hand than what they currently possess. This was also seen in
Pena and Porto's (2008) study where most of the teachers from 150 primary schools in Spain using a CLIL approach did not have specific knowledge of bilingual methodology and required more theoretical knowledge. This leads us to believe that initial teacher licensing programs in English language teaching or modern languages may need to revise their curriculums so that they coincide with the realities related to language teaching in Colombia. Furthermore, a stronger emphasis should be included in these programs on how to teach content area subjects such as math, science, social studies, and geography among others since many of the polled teachers reported that they currently teach content subjects in English without having been properly trained to do so, mainly having been selected as a result of their English proficiency and not content knowledge.

Many teachers in the study expressed that CLIL requires new teaching materials. The participants in the current study claim that far too often the course materials are not adequate for their teaching context, meaning that quite frequently they have to adapt materials in order to make them suitable for their learners. There was no mention as to what type of adaptations were needed or what was being done in terms of content, language, methodological, linguistic, or cognitive adaptations. It is safe to say that teachers still do not seem to be aware of how to properly adapt or adjust materials in accordance with their students' needs and /or interests mainly due to the fact that Colombian language teachers are accustomed to following course books exactly how they are presented. This in turn can be included in formal and informal teacher training programs so that teachers are aware of the benefits of adapting materials in accordance with their context as well as including authentic content to complement current programs. 
It is imperative that teachers include their own personal touch to their instruction, by adapting and or adjusting their lessons in order for their students to benefit from them. This can result in teachers creating their own material in accordance with their context, by creating new avenues of approach for students to access the materials thereby allowing for more success in the CLIL-oriented classroom. As time progresses, these types of adjustments will become much more familiar to them, thus decreasing the time it takes to make additional adjustments.

Almost all of the teachers (92\%) agree that CLIL requires a lot of time for lesson planning and teaching. These results are in accordance with the case studies recently carried out by Cross and Gearson (2012), which also found that teachers need to be well prepared, flexible, and have a high level of proficiency in the CLIL language. This can also be related to the fact that many language programs in Colombia have a high amount of content and a small amount of time to ensure that everything can be delivered. Yet, many of these schools dedicate a huge amount of time to planning, i.e. daily planning, weekly planning, term planning, and unit planning among others.

Cooperation and teamwork are vital components to the successful implementation of a CLIL approach at any given educational institution. Many of the participants agree that CLIL requires cooperation with subject teachers and that a lot of administrative support is required to make CLIL a reality in their contexts. In order for a new pedagogical approach to be implemented into an educational institution, the involvement of the entire educational community/stakeholders is required, mainly due to the fact that CLIL is not and cannot only be isolated to the classroom. Parents, caregivers, and members of the vehicular language (for purposes of this study, I refer to English as the vehicular language) must be involved in order to provide learners with opportunities to further develop and/or be exposed to the new language. In terms of administrative support, decision makers play an important role in CLIL implementation. They need to understand that it is not enough to give the green light to implement, but to better project future decisions, in terms of (a) time for planning, (b) an allocated budget for training and (c) evaluation in which opportunities are provided for both teachers and administrators to be heard.

It is clear that a CLIL approach to language teaching caters to all age levels as $100 \%$ of the teachers all agreed that CLIL can be used for young learners (YL), intermediate as well as adult learners. These results are evident throughout the different levels and types of education (formal and informal settings). CLIL is an approach to education at all levels-no one is left out.

These preliminary results still need to be examined and further developed, considering that the overall objective of this this study is to provide a first look at Content and Language Integrated Learning in Colombia. The samples described within this paper are not representative in order to make informed decisions on CLIL in Colombia. Nevertheless, the data in this first phase is useful to create new data collection instruments that are concerned with material selection, adaption and design, questionnaires for both administrators and students. Further research is needed to determine the effectiveness of CLIL as a viable solution to bilingual education in the Colombian context, looking at it from different angles, public and private institutions, and formal and informal educational settings. Successful strategies need to be explored so as to create a database of best practices that can be developed as part of a CLIL community of practice in Colombia. These findings need to be replicated with larger samples, along with similar contexts and variables. While there is some confidence in the findings due to the fact that they replicate similar projects in other geographical areas, more research is needed. 


\section{References}

Adams, A., E Cox, A. (2008). Questionnaire, in-depth interviews and focus groups. In P. Cairns, $\&$ A. L. Cox (Eds.), Research methods for human-computer interaction (pp. 17-34). Cambridge, UK: Cambridge University Press. Retrieved from https://wiki.engr. illinois.edu/download/attachments/195760983/ a d a m s - c ox - qualit a t i ve - m e t hod s . pdf?version $=1$ EmodificationDate $=1358139440000$

Brinton, D. M., Snow, M. A., \& Wesche, M. B. (2006). Content-based second language instruction. Ann Arbor: University of Michigan Press. (Original work published 1989)

Butler, Y.G. (2005). Content-based instruction in EFL contexts: Considerations for effective implementation. JALT Journal, 27(2), 227-245.

Coyle, D. (1999). Theory and planning for effective classrooms: Supporting students in content and language integrated learning contexts. In J. Masih (Ed.), Learning through a foreign language: Models, methods and outcomes. London: CILT Publications.

Coyle, D., Hood, P., \& Marsh, D. (2010). CLIL: Content and language integrated learning. Cambridge, England: Cambridge University Press.

Cross, R., E Gearson, M. (2012). Research and evaluation of the content and language integrated learning (CLIL) approach to teaching and learning languages in Victorian schools. Melbourne Graduate School of Education. Retrieved online from http://www. education.vic.gov.au/school/principals/curriculum/ Pages/clilvictoria.aspx

Check, J., E Schutt, R. (2012). Research methods in education. University of Massachusetts, Boston: SAGE Publication, Inc. retrieved from http://www. sagepub.com/upm-data/43589_8.pdf

Curtis, A. (2012). Colombian teachers' questions about CLIL: What can teachers' questions tell us? (Part II). Latin American Journal of Content and Language Integrated Learning, 5(2), 1-12. doi:10.5294/ laclil.2012.5.2.6 ISSN 2011-6721.

Darn, S. (2012). CLIL - Content and Integrated Language Learning. [PowerPoint slides] Retrieved from http:// www.istitutogentili.it/clil/CLIL_M1_U1.pdf

Dafouz, E., Núñez, B., Sancho, C., \& Foran, D. (2007). Integrating CLIL at the tertiary level: Teachers' and students' reactions. In D. Wolff $\mathcal{E}$ D. Marsh (Eds.), Diverse contexts, converging goals: Content and language integrated learning in Europe (pp. 91102). Frankfurt, Peter Lang.

Eurydice, European Union Directorate-General for Education and Culture. (2006). Content and language integrated learning (CLIL) at school in Europe. Brussels: Eurydice European Unit. Retrieved from http://ec.europa.eu/languages/documents/ studies/clil-at-school-in-europe_en.pdf

Fricker, R. D., \& Schonlau, M. (2002). Advantages and disadvantages of internet research surveys: Evidence from the literature. Field Methods, 14(4), 347-367. doi: $10.1177 / 152582202237725$.

Grabe, W., \& Stoller, F. L. (1997). Content-based instruction: Research foundations. In M. A. Snow, E D. M. Brinton (Eds.), The content-based classroom: Perspectives on integrating language and content (pp. 5-21). NY: Longman.

Graddol, D. (2005). Spoken everywhere but at what cost? Retrieved from http://www.theguardian. com/theguardian/2005/apr/20/guardianweekly. guardianweekly11

Habte-Gaber, E. (2009). Maintaining Professional Identity in CLIL. Humanising Language Teaching, 11(5). Retrieved from http://www.hltmag.co.uk/oct09/ sart10.htm

Johnson, M. (2012). Bilingual degree teacher's beliefs: A case study in a tertiary setting. Pulso Revista de Educación, 35, 49-74.

Latin American Journal of Content and Language Integrated Learning, LACLIL. (2013). Policies: Focus and Scope. Retrieved online from http:// laclil.unisabana.edu.co/index.php/LACLIL/about/ editorialPolicies\#focusAndScope

Marsh, D. (2006). Using languages to learn and learning to use languages. Retrieved from http://archive.ecml. at/mtp2/clilmatrix/pdf/1UK.pdf

Marsh, D., Mehisto, P., Wolff, D., \& Frigols Martín, M. J. (2011). European Framework for CLIL Teacher Education. A Framework for the Professional Development of CLIL Teachers, http://www.ecml.at/ tabid/277/PublicationID/62/Default.aspx

Massler, U. (2012). Primary CLIL and its stakeholders: What children, parents and teachers think of the potential merits and pitfalls of CLIL modules in primary teaching. International CLIL Research Journal, 1(4), 36-46.

McDougald, J. S. (2009). The state of language and content instruction in Colombia. Latin American Journal of Content $\mathcal{E}$ Language Integrated Learning, 2(2), 44-48. doi:10.5294/laclil.2009.2.2.15.

Mehisto, P. (2008). CLIL counterweights: Recognizing and decreasing disjuncture in CLIL. International CLIL Research Journal, 1(1), 93-119.

Mehisto, P., E Asser, H. (2007). Stakeholder perspectives: CLIL programme management in Estonia. Journal 
of Bilingual Education and Bilingualism, 10(5), 683-701.

Ministerio de Educación Nacional, MEN (2009). Establecimientos Clasificados en Libertad Regulada, que Certifican ante la Secretaría de Educación Ofrecer Educación Bilingüe, y ofrecen Jornada Completa 2009. Retrieved online from http:// www.colombiaaprende.edu.co/html/home/1592/ article-228186.html

Nikula, T., \& Marsh, D. (1996). Kartoitus vieraskielisen opetuksen tarjonnasta peruskouluissa ja lukioissa. Helsinki: Opetushallitus. (Available in English as Language and Content Instruction in the Finnish Primary and Secondary Sectors, Workplace Communication, Continuing Education Centre, University of Jyväskylä, Finland).

Pena Diaz, C., E Porto Requejo, M. D. (2008). Teacher beliefs in a CLIL education project. Porta Linguarum, 10, 151-161.

Rodriguez, M. B. (2011). CLILL: Colombia Leading Into Content Language Learning. Íkala, Revista de Lenguaje y Cultura, 16(28), 79-89.

Ruiz-Garrido, M. F., \& Fortanet-Gómez, I. (2009). Needs analysis in a CLIL context: A transfer from ESP, In D.
Marsh, P. Mehisto, D. Wolff, R. Aliaga, T. Asikainen, M.J. Frigols-Martin, S. Hughes, \& G. Langé (Eds.) CLIL Practice Perspectives from the Field (pp. 179-188). CCN: University of Jyväskylä, 179-188.

Savic, V. (2010). Are we ready for implementing CLIL in primary language classrooms? British Council Serbia ELTA Newsletter, May. Retrieved from http://www. britishcouncil.org/ro/serbia-elta-newsletter-2010may.htm

Secretaria de Educación de Bogotá, SED. (2012). Legalización de colegios bilingües Instituciones de educación formal oficiales y privadas. Retrieved online from: http://www.sedbogota.edu.co/archivos/ Temas\%20estrategicos/Inspeccion/2012/abril/ orientaciones $\% 20$ legalizacion $\% 20$ colegios $\% 20$ bilingues.pdf

Snow, M. A., E Brinton, D. M. (Eds.) (1997). The contentbased classroom: Perspectives on integrating language and content. NY: Longman.

Yassin, S. M., Marsh, D., Tek O. E., E Ying, L. Y. (2009). Learners' perceptions towards the teaching of science through English in Malaysia: A quantitative analysis. International CLIL Research Journal, 1(2), 54-69. Retrieved from http://www.icrj.eu/12/article6.html 


\section{Appendix A}

\section{QUESTIONNAIRE ON TEACHER'S ATTITUDES, PERCEPTIONS \& EXPERIENCES IN CLIL}

This questionnaire is an essential part in getting to understand the attitudes and experiences in as well as the State of the Art of CLIL in Colombia. The questionnaire will take about 10 minutes to complete. The information gathered will be used to aid in understanding the impact of CLIL thus far in Colombia, so that training programs, conferences, events and like can be designed in order to better educate the CLIL community.

Instructions for completion:

Please mark the box with an "X" against the option which most closely represents your answer / views.

Part I. PERSONAL INFORMATION

\begin{tabular}{|l|l|l|l|l|l|}
\hline NAME & \multicolumn{2}{|l|}{} & GENDER & MALE & FEMALE \\
\hline AGE RANGE & $21-30 / 31-40 / 41-50 / 51-60$ & $\begin{array}{l}\text { TEACHING EXPERIENCE } \\
\text { (In years) }\end{array}$ & OTHER & \\
\hline FIRST LANGUAGE & ENGLISH & SPANISH & FRENCH & \\
\hline EMAIL: & \multicolumn{3}{|l|}{} \\
\hline
\end{tabular}

\section{SUBJECT (S) TAUGHT IN FOREIGN LANGUAGE: Please mark all that apply}

\begin{tabular}{|l|l|l|l|}
\hline & History - Philosophy - Religion & & Mathematics-Physics \\
\hline & English - Literature - ESL & & Geography-Social Studies \\
\hline Science -Biology & & Chemistry \\
\hline Technology & & Information Technology \\
\hline & Art-Music-Drama-Dance & Other: \\
\hline
\end{tabular}

STUDENT AGE RANGE:

Please mark all that apply

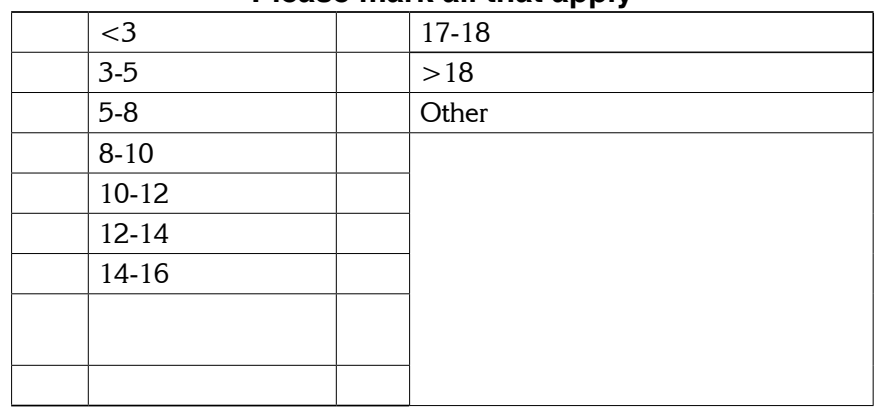




\begin{tabular}{|c|c|c|c|c|c|}
\hline \multicolumn{6}{|c|}{ Part 2. ATTITUDES \& EXPERIENCES IN CLIL } \\
\hline \multirow{2}{*}{$\begin{array}{c}\text { No } \\
1\end{array}$} & \multirow{2}{*}{\begin{tabular}{|r|} 
Statement \\
How much do you know about CLIL
\end{tabular}} & \multicolumn{4}{|c|}{ Criteria } \\
\hline & & A lot & A little & Not Much & \\
\hline 2 & Would like to know more about CLIL? & Yes & No & & \\
\hline 3 & $\begin{array}{l}\text { Would you like to be given the opportunity to teach subject } \\
\text { content (Mathematics, Science, Art, Music, Geography, } \\
\text { Literature, Social Studies ...) through English? }\end{array}$ & Yes & No & & \\
\hline 4 & I have already taught content area(s) through English. & Yes & No & & \\
\hline 5 & $\begin{array}{l}\text { I have helped subject teachers teach subject content through } \\
\text { English. }\end{array}$ & Yes & No & & \\
\hline 6 & $\begin{array}{l}\text { My experience in teaching subject content through English has } \\
\text { been positive. }\end{array}$ & $\begin{array}{l}\text { Strongly } \\
\text { Agree }\end{array}$ & Agree & Disagree & $\begin{array}{l}\text { Strongly } \\
\text { disagree }\end{array}$ \\
\hline 7 & Does CLIL benefit students? & $\begin{array}{l}\text { Strongly } \\
\text { Agree }\end{array}$ & Agree & Disagree & $\begin{array}{l}\text { Strongly } \\
\text { disagree }\end{array}$ \\
\hline 8 & Does CLIL help students develop only their language skills? & $\begin{array}{l}\text { Strongly } \\
\text { Agree }\end{array}$ & Agree & Disagree & $\begin{array}{l}\text { Strongly } \\
\text { disagree }\end{array}$ \\
\hline 9 & Does CLIL help students develop only their subject knowledge? & $\begin{array}{l}\text { Strongly } \\
\text { Agree }\end{array}$ & Agree & Disagree & $\begin{array}{l}\text { Strongly } \\
\text { disagree }\end{array}$ \\
\hline 10 & $\begin{array}{l}\text { Does CLIL help students develop both their language skills and } \\
\text { subject knowledge? }\end{array}$ & $\begin{array}{l}\text { Strongly } \\
\text { Agree }\end{array}$ & Agree & Disagree & $\begin{array}{l}\text { Strongly } \\
\text { disagree }\end{array}$ \\
\hline 11 & $\begin{array}{l}\text { Does CLIL require more methodology knowledge than ELT } \\
\text { teachers possess? }\end{array}$ & $\begin{array}{l}\text { Strongly } \\
\text { Agree }\end{array}$ & Agree & Disagree & $\begin{array}{l}\text { Strongly } \\
\text { disagree }\end{array}$ \\
\hline 12 & $\begin{array}{l}\text { Does CLIL require more subject knowledge than teachers ELT } \\
\text { teachers possess? }\end{array}$ & $\begin{array}{l}\text { Strongly } \\
\text { Agree }\end{array}$ & Agree & Disagree & $\begin{array}{l}\text { Strongly } \\
\text { disagree }\end{array}$ \\
\hline 13 & $\begin{array}{l}\text { Does CLIL require a lot of time (both lesson planning and } \\
\text { teaching)? }\end{array}$ & $\begin{array}{l}\text { Strongly } \\
\text { Agree }\end{array}$ & Agree & Disagree & $\begin{array}{l}\text { Strongly } \\
\text { disagree }\end{array}$ \\
\hline 14 & Does CLIL require new teaching materials? & $\begin{array}{l}\text { Strongly } \\
\text { Agree }\end{array}$ & Agree & Disagree & $\begin{array}{l}\text { Strongly } \\
\text { disagree }\end{array}$ \\
\hline 15 & Does CLIL require a lot of administrative support? & $\begin{array}{l}\text { Strongly } \\
\text { Agree }\end{array}$ & Agree & Disagree & $\begin{array}{l}\text { Strongly } \\
\text { disagree }\end{array}$ \\
\hline 16 & Does CLIL require cooperation with subject teachers? & $\begin{array}{l}\text { Strongly } \\
\text { Agree }\end{array}$ & Agree & Disagree & $\begin{array}{l}\text { Strongly } \\
\text { disagree }\end{array}$ \\
\hline 17 & Is CLIL only possible with intermediate students of English? & $\begin{array}{l}\text { Strongly } \\
\text { Agree }\end{array}$ & Agree & Disagree & $\begin{array}{l}\text { Strongly } \\
\text { disagree }\end{array}$ \\
\hline 18 & Is CLIL only possible with young learners? & $\begin{array}{l}\text { Strongly } \\
\text { Agree }\end{array}$ & Agree & Disagree & $\begin{array}{l}\text { Strongly } \\
\text { disagree }\end{array}$ \\
\hline 19 & Is CLIL only possible with older students? & $\begin{array}{l}\text { Strongly } \\
\text { Agree }\end{array}$ & Agree & Disagree & $\begin{array}{l}\text { Strongly } \\
\text { disagree }\end{array}$ \\
\hline 20 & $\begin{array}{l}\text { Would you be interested in participating in future CLIL research } \\
\text { projects? }\end{array}$ & Yes & No & & \\
\hline
\end{tabular}

THANK YOU VERY MUCH FOR COMPLETING THIS QUESTIONNAIRE 


\section{Appendix B}

Subject(s) Taught in a Foreign Language

\begin{tabular}{|c|c|c|c|c|}
\hline \multicolumn{5}{|c|}{ COMBINATIONS OF SUBJECT(S) TAUGHT } \\
\hline & Frequency & $\%$ & Valid \% & Accumulated \% \\
\hline Accounting & 15 & 10,7 & 10,7 & 17,8 \\
\hline Business Administration & 4 & 2,9 & 2,9 & 13,6 \\
\hline$E F L$ & 2 & 1,4 & 1,4 & 15,0 \\
\hline English-Literature & 25 & 17,9 & 17,9 & 32,9 \\
\hline English-Literature-ESL-EFL & 24 & 17,1 & 17,1 & 50,0 \\
\hline $\begin{array}{l}\text { English-Literature-ESL-EFL, Science-Biology, Geography- } \\
\text { Social Studies }\end{array}$ & 10 & 7,1 & 7,1 & 57,1 \\
\hline $\begin{array}{l}\text { English-Literature-ESL-EFL, Science-Biology, Geography- } \\
\text { Social Studies, Chemistry }\end{array}$ & 2 & 1,4 & 1,4 & 58,6 \\
\hline $\begin{array}{l}\text { English-Literature-ESL-EFL, Science-Biology, } \\
\text { Mathematics-Physics, Geography-Social Studies }\end{array}$ & 15 & 10,7 & 10,7 & 69,3 \\
\hline $\begin{array}{l}\text { English-Literature-ESL-EFL, Science-Biology, } \\
\text { Mathematics-Physics, Geography-Social Studies, Art- } \\
\text { Music-Drama-Dance }\end{array}$ & 1 &, 7 &, 7 & 70,0 \\
\hline $\begin{array}{l}\text { English-Literature-ESL-EFL, Technology, Information } \\
\text { Technology, Art-Music-Drama-Dance }\end{array}$ & 2 & 1,4 & 1,4 & 71,4 \\
\hline English-Literature, Bible & 2 & 1,4 & 1,4 & 72,9 \\
\hline English-Literature, Science-Biology & 3 & 2,1 & 2,1 & 75,0 \\
\hline English-Literature, Science-Biology, Mathematics-Physics & 4 & 2,9 & 2,9 & 77,9 \\
\hline $\begin{array}{l}\text { English-Literature, Science-Biology, Mathematics-Physics, } \\
\text { Geography-Social Studies }\end{array}$ & 1 & ,7 & ,7 & 78,6 \\
\hline English-Spanish & 2 & 1,4 & 1,4 & 80,0 \\
\hline English-Spanish & 2 & 1,4 & 1,4 & 81,4 \\
\hline Ethics & 2 & 1,4 & 1,4 & 82,9 \\
\hline $\begin{array}{l}\text { History - Philosophy - Religion, English-Literature-ESL- } \\
\text { EFL, Geography-Social Studies }\end{array}$ & 2 & 1,4 & 1,4 & 84,3 \\
\hline $\begin{array}{l}\text { History - Philosophy - Religion, English-Literature-ESL- } \\
\text { EFL, Science-Biology, Mathematics-Physics }\end{array}$ & 2 & 1,4 & 1,4 & 85,7 \\
\hline $\begin{array}{l}\text { History - Philosophy - Religion, English-Literature, } \\
\text { Geography-Social Studies }\end{array}$ & 2 & 1,4 & 1,4 & 87,1 \\
\hline Information Technology & 4 & 2,9 & 2,9 & 90,0 \\
\hline Mathematics-Physics & 2 & 1,4 & 1,4 & 91,4 \\
\hline Mathematics-Physics, Chemistry & 1 & ,7 & ,7 & 92,1 \\
\hline Science-Biology, Geography-Social Studies & 1 & ,7 & ,7 & 92,9 \\
\hline Technology, Information Technology, Mathematics-Physics & 8 & 5,7 & 5,7 & 98,6 \\
\hline Technology, Mathematics-Physics & 2 & 1,4 & 1,4 & 100,0 \\
\hline Total & 140 & 100,0 & 100,0 & \\
\hline
\end{tabular}




\title{
Appendix C
}

\author{
Consent Form
}

TITLE OF RESEARCH PROJECT: The State of the Art of Content Language Learning (CLIL) in Bogotá Colombia: What are teachers' attitudes, perceptions and experiences in CLIL?

\section{INVESTIGATOR:}

Universidad de La Sabana requires the following informed consent for any person involved in a research study conducted by investigators at the University.

\section{You have:}

A. Provided me with a detailed explanation of the procedures to be followed in the project, including an identification of those, which are experimental.

This research will attempt to capture information on CLIL at the subject's institutions as the first step in the formation of a database in establishing a State of the Art of CLIL in Latin America that would be of immediate value and applicability for educators, researchers and policy-makers and, simultaneously, to place Latin American research on CLIL within a broader global context.

I understand I will be asked to complete questionnaires, participate in a focus group in which the session may be audio / video taped and later transcribed. In addition I will be asked to answer a set of questions during these sessions.

B. Answered any questions that I have regarding the study.

I understand that:

A. My participation is voluntary, and I may withdraw my consent and discontinue participation in the project at any time. My refusal to participate will not result in any penalty.

B. By signing this agreement, I do not waive any legal rights or release you from liability for negligence.

If you have any questions about the study, please feel free to contact XXX at Email: XXX Office Phone: XXX Cell Phone number: XXX-XXX-XXXX

Hereby give my consent to be a participant in the research project.

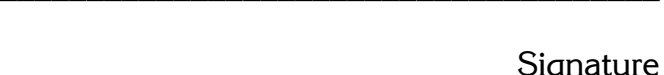

Signature

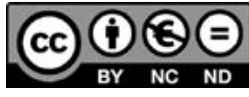

Date 